\title{
Problem Based Learning, Discovery Learning, and Open Ended Models: An experiment On Mathematical Problem Solving Ability
}

\author{
Dian Fitria Tanjung1, Edi Syahputra ${ }^{2}$, Irvan ${ }^{3}$ \\ 1Pendidikan Matematika, Program Pascasarjana Universitas Muhammadiyah Sumatera Utara, Indonesia \\ 2Pendidikan Matematika, Universitas Negeri Medan, Indonesia \\ 3Pendidikan Matematika, Universitas Muhammadiyah Sumatera Utara, Indonesia \\ 1dyanfitrya612@gmail.com, 2edisyahputra01.es@gmail.com, $\underline{3 \text { irvan@umsu.ac.id }}$
}

\begin{tabular}{l}
\hline \hline \\
\hline Article History: \\
Received : 28-01-2020 \\
Revised $1: 08-03-2020$ \\
Revised $2: 27-03-2020$ \\
Accepted : 28-03-2020 \\
Online : 02-04-2020 \\
\hline
\end{tabular}

\section{Keyword:}

Problem Based Learning; Discovery Learning; Open Ended; Mathematical Problem Solving Ability.

Tor

\begin{abstract}
This research is to look at the effect of problem-based learning, discovery learning, and open-ended models on the mathematical problem-solving abilities of students. The type of research is a quasi-experiment with a three treatment counterbalanced design research design. The instruments used: (1) students 'initial mathematical ability tests, (2) tests of students' mathematical problemsolving abilities with the Pythagorean Theorem material. Inferential data were performed using covariance analysis (ANACOVA). The samples of this study were 32 students each from three experimental classes selected by purposive sampling. The results are: (1) of the three learning models conducted using the model of problem-based learning, discovery learning, and open-ended had a positive effect on the ability to solve mathematical problems; (2) the ability to solve mathematical problems of students taught by problem-based learning models is better than the using discovery learning and open-ended models; and (3) there is an interaction between the initial ability of mathematics and learning models.
\end{abstract}

ABSTRACT doi) Crossref

https://doi.org/10.31764/itam.v4i1.1736

\section{(c) (1) (2)}

This is an open access article under the CC-BY-SA license

\section{A. INTRODUCTION}

The initial step of students' preparation in following the learning process is that students must have initial abilities. Initial abilities are obtained based on prior knowledge. The initial ability illustrates the readiness of students to receive lessons delivered by the teacher, to find out how far students master the subject matter (Knecht-Sabres, 2013). So with this initial ability the teacher can design learning better.

In learning in school, mathematics is a lesson that can train students to think logically, solve a problem in real life, be able to think critically and creatively. Therefore, mathematics lessons need to be mastered and studied by students. Besides mathematics needs to be mastered and studied, students must also have some abilities. Based on the type Hendriana \& Soemarmo (2014) and Friesen (2016) suggested that Mathematical abilities are classified into 
five main competencies, namely: mathematical understanding, mathematical problem solving, mathematical communication, mathematical connection, and mathematical reasoning. Problem solving will be examined in this regard.

Problem solving abilities pay attention to understanding problems, the importance of students learning problem solving, steps and problem solving strategies. Then students must be knowing, understand, and can apply the process of problem solving mathematics itself. The ability to solve mathematical problems is also an important component in the process of learning mathematics that supports students' mathematical activities, so the ability of problem solving among students needs attention in learning.

The 2014 Education Assessment Centre Team said, "students' difficulty in solving nonroutine problem solving problems is caused by the attachment of Indonesian students to the ready-made formula as a product". This means that the mathematics learning process carried out in class only emphasizes memorizing the ready-made formula and has not facilitated students to be able to solve a given problem. In fact, in the initial research at SMP Negeri 1 Percut Sei Tuan the level of students' initial mathematical abilities was still in the medium and low categories. It is seen that students still experience problems when solving problems. From the students' answer process, the problem solving that was done was still not optimal and still not quite right students need better mathematical problem solving skills . In this material students are still fixated on the sample questions given, whereas in the 2013 curriculum students are required to be more creative in problem solving, so that learning activities still do not fully meet expectations in accordance with learning objectives. So it needs to be seen what factors make the problem-solving ability is not optimal.

In the learning process also requires a learning model that can make students better at solving mathematical problems. One alternative used should be a student-centered learning model, and can facilitate students learning to solve the given problem. Some of the learning models that want to be used in this case are problem based learning (PBL), discovery learning (DL) and open ended (OE) models.

Problem based learning is a learning model that is designed to use problems in real life and emphasizes the use of problems as a means for students to develop critical and creative thinking skills in solving real problems (Susanto \& Retnawati, 2016). Problem based learning is a learning model that provides authentic experiences that encourage students to learn actively, construct knowledge, and integrate the context of school learning and learning in real life naturally (Abidin, 2014), (Danişman \& Karadağ, 2015). In problem based learning, it is the one who is raised who needs it Authentic investigative investigation skills and higherorder thinking skills can be developed. New knowledge and experience gained by using previous knowledge and experience. So, the problem is there used as a means for students to learn something that can support science (Astriani, Surya, \& Syahputra, 2017).

In problem based learning it is emphasized that learning begins with the presentation of the problem. Therefore, problem-based learning begins with solving a problem, and the problem posed to students must be able to provide new information or ideas so that students gain new knowledge before they can solve the problem.

Decellation learning is a learning model that changes teacher-centered learning be student-centered learning (Handayani, Hajidin, Duskri, \& Maidiyah, 2018). Discovery learning is a learning model to develop active student learning by discovering on their own, investigating on their own, so the results obtained will last long in memory, students will not be easily forgotten (Wicaksana \& Usodo, 2016). Decellation learning is a learning model that can stimulate students' ability to think creatively, analytically, systematically, and logically to find alternative problem solving by exploring data to foster scientific attitudes (Yuliasari, 2017), (Simamora, Saragih, \& Hasratuddin, 2018). So that discovery learning is a learning model that changes learning ranging from teacher-centered to student-centered learning so 
that students learn actively by finding themselves, investigating themselves and growing scientific attitudes in accordance with the stages of discovery learning, namely: (1) Stimulation, (2) Problem statement, (3) Data collection (4) Data processing, (5) Proof, (6) Generalization (drawing conclusions).

According to Shimada \& Becker in Gordah, Fadhilah, \& Syarifah (2014) and Cunningham Moss, (2015) open ended is a learning approach that starts from introducing students on open problems. Learning continues by using many correct answers to the problems given to provide experience to students in finding something new in the learning process. Open ended learning is a way of presenting teaching material through issues raised openly and contextually so as to form a mindset, cohesiveness, openness and variety of thinking (Mousa, 2017). Meanwhile according to Sejpal (2013) stated that the approach open ended is a learning process in which individual/student goals and desires are built and achieved openly, not only open ended goals can also refer to ways to achieve the learning goals themselves. According to Rahma, Novtiar, \& Sugandi (2018) the purpose of the open ended approach is to help develop students' creative activities and mathematical thinking patterns through simultaneous problem solving. In other words, students 'creative activities and mathematical thought patterns must be developed to the maximum extent possible in accordance with students' abilities.

So the open ended approach is a learning approach that begins by presenting teaching material through the problems raised openly and contextually so as to form a mindset in accordance with the steps, namely (1) Facing students to open problems and how students arrive at a solution, (2) Guiding students to solve the problem yourself, (3) Letting students solve problems with various solutions and diverse answers, and (4) Asking students to present their findings.

Problem based learning has a good influence on elementary linear algebra courses (Maryanti \& Kurniawan, 2018). Likewise the results of other studies indicate that the model of problem based learning is effective in improving students mathematical problem solving skills in the medium category (Mushlihuddin, Nurafifah, \& Irvan, 2018).

With the development of discovery learning model devices will improve (Damanik \& Syahputra, 2018). Other results of the discovery learning model the ability to submit problems will increase as well as the results of research (Gustiani, Irman, Fadhillah, Sri, \& Model, 2019). Learning with an open ended approach to students' mathematical problem solving abilities will increase (Nasution, 2017). By using an open ended approach to problem solving skills can achieve mastery learning (Purwaningrum, 2014). It can be concluded that the model of problem based learning, discovery learning and open ended learning is an alternative learning that can train students' mathematical problem solving skills in achieving the learning process.

In connection with the description above and from the results of existing research, it is necessary to see the effect of Problem based learning, discovery learning, and open ended on the ability to solve mathematical problems as well as the interaction of learning models used between the initial ability to the mathematical problem solving abilities of students.

\section{B. METHODS}

\section{Types of research}

This research is quantitative using the quasi experiment. The purpose of this study is a three counter balanced design that was implemented at SMP Negeri 1 Percut Sei Tuan. This research sample consists of three classes. 


\section{Research Population}

The population of this research are students of class VIII, amounting to 299 students who were divided into 9 study group. The sample in this study amounted to 32 students from each class. The classes used are 3 experimental classes with different models. The sampling technique in this study was conducted with a purposive sampling technique. Purposive sampling technique according to Sugiyono (2016) is a sampling technique with certain considerations. In this study was taken based on an agreement between the school and the researcher. This was done so as not to interfere with much activity in school.

\section{Data Collection Technique}

Data collection techniques in this study is to use tests and non-tests to measure the initial ability of mathematics and the final test to measure the ability to solve mathematical problems. Data obtained through tests are used to see the effect of problem and discovery learning.

\section{Data Analysis}

For the first data analysis using descriptive analysis. The data described is data obtained from measurements on variables research variable (dependent variable). The research data analyzed were the initial mathematical ability and post-test data on aspects of mathematical problem solving ability. The second data analysis is by using inferential analysis which consists of: normality test, homogeneity test and hypothesis test using ANACOVA by SPSS software version 23. The hypothesis that will be tested is to see the effect of PBL, DL and OE learning models on mathematical problem solving abilities, as well as the interaction between initial abilities and learning models on mathematical problem solving abilities. The data to be analyzed in this study are the initial ability as a accompanying variable and the results of the post-test (final ability) as the dependent variable. The use of ANACOVA is caused in this study using accompanying variables as independent variables that are difficult to control but can be measured together with the dependent variable. Mathematical models for analysis of covariance are expressed as follows (Syahputra, 2016).

$$
\begin{aligned}
& Y_{i j k}=\mu_{\ldots}+\alpha_{i}+\beta_{j}+(\alpha \beta)_{i j}+\cdots+\epsilon_{i j K} \\
& i=1,2,3 ; j=1,2,3 ; k=1,2,3, \cdots, 32
\end{aligned}
$$

With $\boldsymbol{Y}_{\boldsymbol{i j k}}$ is Scores of students' math problem solving skills, $\boldsymbol{\mu}$ is the average scores of students' mathematical problem solving skills, $\boldsymbol{\beta}$ is the effect of learning model on students' mathematical problem solving skills; $\boldsymbol{\alpha} \boldsymbol{\beta}_{i j}$ is the influence of interaction between the KAM and the learning model of students' mathematical problem-solving skills, and $\boldsymbol{E}_{\boldsymbol{i j k}}$ is an error component that arises in the K students.

\section{RESULTS AND DISCUSSIONS}

\section{Description of the results of tests of early mathematical abilities and the ability to} solve mathematical problems

The analysis of mathematical problem solving abilities is carried out twice, namely at the beginning of learning to see students initial mathematical abilities and final tests to see students mathematical problem solving abilities. So for this purpose, researchers used questions that were adapted from elementary school National Exam questions. The question consisted of 35 multiple choice questions. To get a picture of students initial mathematical abilities, the mean and standard deviation is calculated. The complete calculation results can be seen in the appendix, while the summary results in Table 1 below: 
12 | JTAM (Jurnal Teori dan Aplikasi Matematika) | Vol. 4, No. 1, April 2020, pp. 9-16

Table 1. Early Mathematics Ability (KAM) 3 models (PBL, DL and OE)

\begin{tabular}{lccccc}
\hline \multicolumn{1}{c}{ Method } & N & Min & Max & Mean & Std. Deviation \\
\hline KAM-PBL & 32 & 79.00 & 91.00 & 83,31 & 2.96689 \\
\hline KAM-DL & 32 & 78.00 & 91.00 & 82.81 & 3,20722 \\
\hline KAM-OE & 32 & 78.00 & 90.00 & 82.43 & 2.85044 \\
\hline Valid N (List wise) & 32 & & & & \\
\hline
\end{tabular}

From Table 1 it can be seen that the initial mathematical ability of students with moderate criteria is more dominant than the initial mathematical ability with high criteria and the initial mathematical ability with low criteria. At the second meeting after the students' initial mathematics proficiency tests, the three experimental classes used data midterm exam (MID) value semester 1 first before learning is carried out in each experimental class. At the last meeting, each experimental class was given a test to look back abilities after the learning process was carried out, whether or not there was an improvement that can be seen in Table 2 below.

Table 2. Data on Test Results for Students' Mathematical Problem Solving Abilities (KPM) Using Problem Based Learning, Discovery Learning and Open Ended

\begin{tabular}{lccccc}
\hline \multicolumn{1}{c}{ Method } & N & Min & Max & Mean & Std. Deviation \\
\hline KPM-PBL & 32 & 37.00 & 39.00 & 37.28 & 5.2267 \\
\hline KPM-DL & 32 & 33.00 & 38.00 & 35.46 & 1.2439 \\
\hline KPM-OE & 32 & 29.00 & 34.00 & 31.75 & 1.3678 \\
\hline Valid N (list wise) & 32 & & & & \\
\hline
\end{tabular}

It can be seen that the comparison of the scores of the three experimental classes, the lowest value is in the open ended model and the highest value is the problem based learning model.

\section{ANACOVA model of problem based learning, discovery learning and open ended to problem solving abilities}

Furthermore, testing the hypothesis that will be tested using ANACOVA includes:

a. The effect of problem based learning on the ability to solve mathematical problems

The results of hypothesis testing assisted by SPSS version 23 can be seen in the following Table 3.

Table 3. Results Hypothesis Testing PBL Model Against the Problem Solving Ability (KPM1)

Dependent Variable: Problem Solving Ability 1 (KPM1)

\begin{tabular}{lccccc}
\hline \multicolumn{1}{c}{ Source } & Type III Sum of Squares & df & Mean Square & F & Sig. \\
\hline Prototype & 1148.893 a & 12 & 95.741 & 2.321 & 0.049 \\
\hline Cut of & 164541.542 & 1 & 164541.542 & 3989.018 & 0.000 \\
\hline PBL & 1148.893 & 12 & 95.741 & 2.321 & 0.049 \\
\hline Error & 783.724 & 19 & 41.249 & & \\
\hline Total & 255315.625 & 32 & & & \\
\hline Total of correct & 1932.617 & 31 & & & \\
\hline a. R Squared $=0.594$ (Adjusted R Squared $=0.338$ ) & & &
\end{tabular}

It can be seen that the $\mathrm{F}$ value in the problem based learning column is 2.321 with a significant value of $0.049<0.05$ which means $\mathrm{H}_{0}$ is rejected. In other words, there is a significant influence between problem based learning models on students mathematical problem solving abilities. 
b. The effect of discovery learning on the ability to solve mathematical problems Hypothesis test results seen in Table 4 below:

Table 4. Results Hypothesis Testing of Discovery Learning Model (DL) Against Problem Solving Ability (KPM2)

\begin{tabular}{lrrrrr}
\hline \multicolumn{7}{c}{ Dependent variable: Problem Solving Ability (KPM2) } & & \\
\hline Source & Type III Sum of Squares & df & Mean Square & \multicolumn{1}{c}{ F } & \multicolumn{1}{c}{ Sig. } \\
\hline Corrected Model & 170.219 a & 9 & 18.913 & 3.715 & 0.006 \\
\hline Intercept & 138045.037 & 1 & 138045.037 & 27115.989 & 0.000 \\
\hline DL & 180.219 & 10 & 18.713 & 3.815 & 0.006 \\
\hline Error & 112.000 & 21 & 5.101 & & \\
\hline Total & 221561.000 & 32 & & & \\
\hline Corrected Total & 282.219 & 31 & & & \\
\hline a. R Squared $=0.603$ (Adjusted R Squared $=0.441)$ & & & & \\
\hline
\end{tabular}

The $\mathrm{F}$ value in the discovery learning column was 3.715 with a significant value of $0.006<0.05$ which means that $\mathrm{H}_{0}$ was rejected. In other words, there is a significant influence between discovery learning models on students' mathematical problem solving abilities.

c. The effect of open ended on the ability to solve mathematical problems

The results of the hypothesis can be seen in Table 5 below:

Table 5. Results Hypothesis Testing Open Ended (OE) Model Against Problem Solving Ability (KPM3)

Dependent Variable: Problem Solving Ability 3 (KPM3)

\begin{tabular}{lrrrrr}
\hline \multicolumn{1}{c}{ Source } & Type III Sum of Squares & df & Mean Square & \multicolumn{1}{c}{ F } & \multicolumn{1}{c}{ Sig. } \\
\hline Model of correct & 170.219 a & 9 & 18.913 & 3.715 & 0.006 \\
\hline Intercept & 138045.037 & 1 & 138045.037 & 27115.989 & 0.000 \\
\hline OE & 170.219 & 9 & 18.913 & 3.715 & 0.006 \\
\hline Error & 112.000 & 22 & 5.091 & & \\
\hline Total & 221561.000 & 32 & & & \\
\hline Corrected for Total & 282.219 & 31 & & & \\
\hline a. R Squared = 0.603 (Adjusted R Squared $=0.441)$ \\
\hline
\end{tabular}

d. Interactions between early mathematical abilities and learning models on problem solving abilities

Hypothesis test results are shown in Table 6 below:

Table 6. Results Hypothesis Testing Interactions between early mathematical abilities (KAM) and learning models on problem solving abilities (KPM)

Dependent Variable: Problem Solving Abilities (KPM)

\begin{tabular}{lrrrrr}
\hline \multicolumn{1}{c}{ Source } & Type III Sum of Squares & df & Mean Square & \multicolumn{1}{c}{ F } & \multicolumn{1}{c}{ Sig. } \\
\hline Corrected Model & $1028.705^{\text {a }}$ & 77 & 13.360 & 382.722 & 0.000 \\
\hline Intercept & 1.948 & 1 & 1.948 & 55.794 & 0.000 \\
\hline MID & 219.747 & 1 & 219.747 & 6295.144 & 0.000 \\
\hline KAM & 0.326 & 13 & 0.025 & 0.717 & 0.726 \\
\hline MODEL & 159.063 & 20 & 7.953 & 227.836 & 0.000 \\
\hline KAM * MODEL & 1.550 & 43 & 0.036 & 1.032 & 0.490 \\
\hline Error & 0.628 & 18 & 0.035 & & \\
\hline Total & 134533.500 & 96 & & & \\
\hline Corrected Total & 1029.333 & 95 & & & \\
\hline a. Squared of R $=0.999$ (Adjusted R Squared $=0.997)$ \\
\hline
\end{tabular}


From Table 6 it can be seen that the significant number on the variable midterm exam (MID) value is $0.000<0.05$, which means rejected, so that there is a linear relationship between midterm exam with students' mathematical problem solving abilities and assumptions of covariance analysis which require linearity between accompaniment variables ( covariant) with dependent variables has been fulfilled.

Furthermore, to see the cause of learning on students' mathematical problem solving abilities, by ignoring the effect of the initial mathematical ability of the model it appears that the significance number is $0.000<0.05$ which means was rejected. Then there is an impact of learning models on students' mathematical problem solving abilities.

The effect of initial mathematical ability and differences in learning models simultaneously, can be seen in the Corrected Model with a significance value of $0.000<0.05$ which means was rejected. This means that at the $95 \%$ level, students 'initial mathematical abilities and differences in the model of problem based learning, discovery learning and open ended simultaneously (simultaneously) affect the ability of students' mathematical problem solving.

Based on the results of statistical tests that have been conducted, it can be concluded that the learning model provides a significant influence in the learning process. From the results of the calculation of mathematical problem solving abilities, those using problem based learning and discovery learning are superior to those using the open ended model. The high score of students' mathematical problem solving abilities with problem based learning models is caused by several things, one of which is learning that requires students to find out, find themselves and construct their knowledge by using information obtained or prior student learning experiences.

In discovery learning the score of students mathematical problem solving abilities is superior to that of open ended. One factor students are superior to the open ended model is the presence of students' teacher direction in developing their ideas. Another case with the open ended model that requires students to think more creatively in finding solutions to a problem given with more varied answers or answer processes. These three learning models have good influence and are suitable to be used to provide variations in the learning model if it is adapted to the student's situation.

\section{CONCLUTIONS AND SUGGESTIONS}

Based on the research results can be learned several conclusions: (1) Of the three learning models carried out using the model of problem based learning, discovery learning, and open ended have a positive influence on students' mathematical problem solving abilities; (2) Ability to solve mathematical problems taught by using problem based learning is better than the ability to solve mathematical discovery learning and open ended; and (3) There is an interaction between the initial ability of mathematics and learning models that take place on the ability to solve students' mathematical problems.

Furthermore, the authors suggest further research that examines early mathematical abilities and variations of other learning models on the ability to solve mathematical problems in other appropriate material and with other aspects such as the ability to think creatively, and the ability to think critically.

\section{ACKNOWLEDGEMENT}

We are grateful for the support, assitance and enthusiasm of the supervisors at SMP Negeri 1 Percut Sei Tuan. 


\section{REFERENCES}

Abidin, J. (2014). Learning System Design in the Context of Curriculum 2013. Bandung: PT Refika Aditama.

Astriani, N., Surya, E., \& Syahputra, E. (2017). The Effect Of Problem Based Learning To Students' Mathematical Problem Solving Ability. International Journal of Advance Research And Innovative Ideas In Education, 3(2), 3441-3446.

Cunningham Moss, L. (2015). Argumentation through policy-analysis: Designing effective standardsbased mathematics for social justice instruction. (Vol. 75).

Damanik, W. J., \& Syahputra, E. . (2018). Pengembangan Perangkat Pembelajaran Untuk Menigkatkan Kemampuan Berpikir Kreatif Matematis Siswa Menggunakan Model Discovery Learning. Inspiratif: Jurnal Pendidikan Matematika, 4(1). https://doi.org/10.24114/jpmi.v4i1.9294

Danişman, Ş., \& Karadağ, E. (2015). Comparison of 2005 and 2013 5th Grade Mathematics Curriculums in the context of Learning Domains and Objectives. Turkish Journal of Computer and Mathematics Education (TURCOMAT), 6(3), 380. https://doi.org/10.16949/turcomat.03423

Friesen, S. (2016). Assessment for Learning in a Math Classroom. https://doi.org/10.1007/978-3-31923347-5_6

Gordah, E., Fadhilah, \& Syarifah. (2014). Teacher's Efforts to Improve Connection and Solution Abilities Mathematical Problems of Students Through the Open Ended Approach. Journal of Education and Culture, 20(3), 80-92.

Gustiani, D. S., Irman, A., Fadhillah, F. M., Sri, D., \& Model, L. (2019). Discovery Learning Model and Statistical Cenic in Improving Mathematical Communication Ability Students. Journal of Innovative Mathematics Learning, 2(1), 29-38.

Handayani, R., Hajidin, Duskri, M., \& Maidiyah, E. (2018). Development of learning tools using Treffinger learning model to improve creative thinking. Journal of Physics: Conference Series, 1088. https://doi.org/10.1088/1742-6596/1088/1/012090

Hendriana, H., \& Soemarmo, U. (2014). Mathematics Learning Assessment. Bandung: PT Refika Aditama.

Knecht-Sabres, L. J. (2013). Experiential Learning in Occupational Therapy: Can It Enhance Readiness for Clinical Practice? Journal of Experiential Education, 36(1), 22-36. https://doi.org/10.1177/1053825913481584

Maryanti, S., \& Kurniawan, D. T. (2018). Pengembangan Media Pembelajaran Video Animasi Stop Motion Untuk Pembelajaran Biologi Dengan Aplikasi Picpac. Jurnal BIOEDUIN : Program Studi Pendidikan Biologi, 8(1), 26-33. https://doi.org/10.15575/bioeduin.v8i1.2922

Mousa, Y. K. (2017). Cooperative Learning Strategies Principles And Techniques. $\square \square \square \square \square \square$

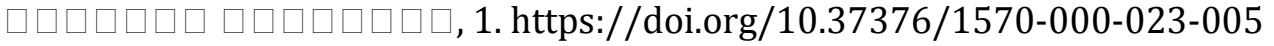

Mushlihuddin, R., Nurafifah, N., \& Irvan, I. (2018). The effectiveness of problem-based learning on students' problem solving ability in vector analysis course. Journal of Physics: Conference Series, 948(1). https://doi.org/10.1088/1742-6596/948/1/012028

Nasution, E. Y. P. (2017). Meningkatkan Kemampuan Berpikir Kreatif Siswa Melalui Pendekatan Open Ended. Jurnal Inovasi Pendidikan Dan Pembelajaran Matematika, 3(2), 1-15.

Purwaningrum, J. P. (2014). Creative Thinking Ability Viewed from The Aspect of Adversity Quotient Through Mathematics Problem Solving Learning Type "What's Another Way" (Research Proposal in Junior High School). International Conference on Mathematics, Science, and Education.

Rahma, A. F., Novtiar, C., \& Sugandi, A. I. (2018). Meningkatkan Kemampuan Berpikir Kreatif Matematis Siswa Kelas Viii Mts Negeri Sukasari Cimahi Pada Materi Sistem Persamaan Linear Dua Variabel Menggunakan Pendekatan Open-Ended. JPMI (Jurnal Pembelajaran Matematika Inovatif), 1(2), 139. https://doi.org/10.22460/jpmi.v1i2.p139-144

Sejpal, K. (2013). Models of Teaching: The Way of Learning. International Journal for Research in Education, 2(3), 18-24.

Simamora, R. E., Saragih, S., \& Hasratuddin, H. (2018). Improving Students' Mathematical Problem Solving Ability and Self-Efficacy through Guided Discovery Learning in Local Culture Context. International Electronic Journal of Mathematics Education, 14(1). https://doi.org/10.12973/iejme/3966

Sugiyono. (2016). Research Methods Quantitative, Qualitative, and R\&D. In Bandung: Alfabeta. 
16 | JTAM (Jurnal Teori dan Aplikasi Matematika) | Vol. 4, No. 1, April 2020, pp. 9-16

https://doi.org/10.1017/CB09781107415324.004

Susanto, E., \& Retnawati, H. (2016). Perangkat pembelajaran matematika bercirikan PBL untuk mengembangkan HOTS siswa SMA. Jurnal Riset Pendidikan Matematika, 3(2), 189. https://doi.org/10.21831/jrpm.v3i2.10631

Syahputra, E. (2016). Applied Statistics. Medan: Unimed Press.

Wicaksana, H., \& Usodo, B. (2016). Eksperimentasi Model Pembelajaran Problem Based Learning (PBL) dan Discovery Learning (DL) dengan Pendekatan Saintifik pada Materi Himpunan Ditinjau dari Adversity Quotient (AQ) Siswa. Jurnal Elektronik Pembelajaran Matematika, 4(3), 258-269.

Yuliasari, E. (2017). Eksperimentasi Model PBL dan Model GDL Terhadap Kemampuan Pemecahan Masalah Matematis Ditinjau dari Kemandirian Belajar. JIPM Ournal Ilmiah Pendidikan Matematika), 6(1), 1. https://doi.org/10.25273/jipm.v6i1.1336 